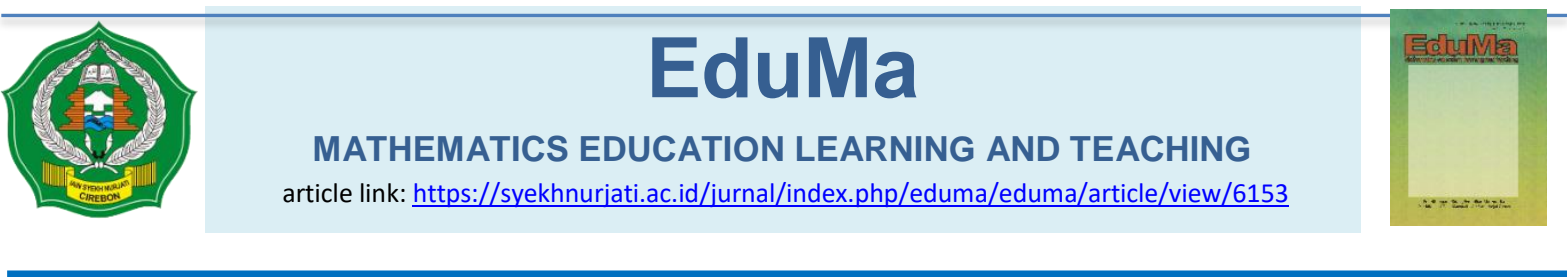

\title{
Analysis of Student's Creative Thinking Ability in Mathematical Problem Solving in Terms of Extrovert and Introvert Personality Types
}

\author{
Habibah Intan Sari ${ }^{*}$, Mumun Munawaroh ${ }^{2}$, Hendri Raharjo ${ }^{3}$ \\ 1, 2, 3 Department of Mathematics Education, Institut Agama Islam Negeri Syekh Nurjati Cirebon, Indonesia
}

*Corresponding author: Department of Mathematics Education, Institut Agama Islam Negeri Syekh Nurjati Cirebon, Indonesia. e-mail addresses: habibahintansari_std@ syekhnurjati.ac.id

\begin{tabular}{l}
\hline $\mathbf{a} \mathbf{i} \mathbf{i} \mathbf{l} \mathbf{i} \mathbf{f}$ \\
\hline How to cite this article: \\
Sari, Habibah Intan., Munawaroh, Mumun., \& \\
Raharjo, Hendri, A3. (2020). Title of Article. \\
Eduma : Mathematics Education Learning And \\
Teaching, 9(1), 34 - 42. \\
doi:http://dx.doi.org/10.24235/eduma.v\%vi\%i.6153
\end{tabular}

Article history:

Received: 03 01, 2020

Accepted: 0323,2020

Published: 07, 2020

Copyright (C) 2020

EduMa: Mathematics Education Learning and Teaching under the Creative Commons Attribution 4.0 International License.

\section{a b s t r a c t}

ANALYSIS OF STUDENT'S CREATIVE THINKING ABILITY IN MATHEMATICAL PROBLEM SOLVING IN TERMS OF EXTROVERT AND INTROVERT PERSONALITY TYPES. This research is motivated by differences in personality types that cause differences in creative thinking ability based on its level. Therefore, indicators of creative thinking ability used are fluency, flexibility, and originality. The research method used is descriptive with a qualitative approach. The research subjects were 4 students of class X IPS MA An-Nur Cirebon City which were selected based on consideration of the results of personality tests. The instruments used were personality tests, tests of creative thinking ability, and interviews. Data analysis techniques include data reduction, triangulation, data presentation, and concluding. The results showed that: (1) Students who tended extrovert personality types were at the level of creative thinking ability 1 (less creative). (2) Students who tended introvert personality types were at the level of creative thinking ability 3 (creative).

\section{Key word s :}

Creative Thinking Ability; Mathematical Problem Solving; Extrovert and Introvert Personality Types 


\section{INTRODUCTION}

Mathematics is a science that is not far from the reality of human life. Its existence is inseparable from our daily lives in various fields. According to Purwosusilo (2014, p. 31), mathematics is a science that is needed in various fields, both for mathematics itself and other fields. Mathematics requires students to be faced with various kinds of challenges in an organized way, formulating innovative questions by designing original solutions to foster student knowledge. Therefore, students must think about how to deal with those challenges to find a solution. That is where the students are doing a pro s ice thinking. A thought process is an event of mixing, matching, combining, exchanging, and sorting of concepts, perceptions, and previous experiences (Kuswana, 2011). Therefore, in solving problems, especially mathematical problems, you must first go through the process of thinking.

In the process of thinking it takes the socalled ability to think. One of them is the creative thinking ability. The creative thinking ability is the ability to generate ideas or new ideas in generating a way of solving problems, even generating new ways as alternative solutions (Lestari \& Yudhanegara, 2017). Therefore, the ability to think creatively in the learning process mathematics required. Thus, this ability is very basic for individuals to solve problems creatively.

Creative thinking is a process that occurs in the brain and mind carried out by a creative person (Sunandar \& Muchyidin, 2016). Creativity is a product of the ability to think (in this case creative thinking) to produce a new way or something in looking at a problem or situation (Siswono, 2018). "Creative personality" is personality traits that are timeless and relatively stable over time that is manifested in creative behavior and affect creative thinking that points to the possibility of creative performance, personality disposition is carried out regularly and is thought to be related to creative achievement. An alternative to personality traits is a personality type.

Personality is a reaction given by someone to someone else that is obtained from what is thought, felt and done which is revealed through behavior in daily life. One tendency of personality types that exist in humans based on Jung's theory is the personality type in the attitude of the human soul, namely extroverts and introverts. Based on this, it is clear that if associated with understanding, extroverted and introverted personalities also play an important role in their thought process activities. Nana Hasanah (2013, p. 424) states that students with different personality types will also have different thought processes. Therefore, a teacher needs to recognize the diversity of the personality traits of his students so that he easily makes a personal approach with them to encourage a more effective teaching process.

Based on the Field Experience Practices (PPL) activities that researchers conducted previously, information obtained that in reality there are still many students who have difficulty in solving mathematical problems, especially in class X IPS MA An-Nur Cirebon which is the focus of this study. In this class, there are various types of personalities, although all students are female. It does not rule out the possibility that differences in personality types will cause different thinking abilities in each individual, especially in the realm of creative thinking.

In this regard, several factors cause students difficulty in solving divergent mathematical problems, one of which is that students lack understanding of what they often face and are considered difficult so that students do not explore the answers. In this case, the ability to think creatively is needed by students in the process of solving mathematical problems 
they face in each problem given by their teacher. There are also various levels in the ability to think creatively so that it can be known as the level of creative thinking ability based on personality types. Therefore, researchers conducted a study entitled "Analysis of Students' Creative Thinking Ability in Solving Mathematical Problems in terms of Extrovert and Introvert Personality Types".

\section{LITERATURE REVIEW}

\section{Creative Thinking Ability}

The ability to think creatively is the ability to generate ideas or new ideas in generating a way of solving problems, even generating new ways as alternative solutions (Lestari \& Yudhanegara, 2017, p. 89). Therefore, the ability to think creatively in the process of learning mathematics is very necessary, because this ability is very basic for individuals to solve problems creatively.

Siswono (2008, p. 42) formulates the level of creative thinking abilities in mathematics, namely: level 4 (very creative), level 3 (creative), level 2 (quite creative), level 1 (less creative), level 0 (not creative).

In this case, indicators of creative thinking abilities that are used are fluency, flexibility, and novelty (Siswono, 2018, p. 135) :

a. Fluency, which has many ideas that can provide a variety of ways even though there is no conceptually striking difference.

b. Flexibility, shown in ways or methods that are conceptually or procedurally different in more than one way.

c. Novelty, which has a unique idea and is different from the general way to solve problems.

\section{Mathematical Problem Solving}

In learning mathematics, problem-solving is a result of abilities that students must achieve. The ability to solve problems is needed by students, both at school and in the community. Considering that in everyday life there are certainly many problems encountered related to mathematics (Tho'atillah, 2018).

Siswono (2018, p. 123) explained the opinion of Pehkonen, that to encourage the creativity of thinking in mathematics the concept of a problem will be used in a task situation that asks students to connect information that is known and information in the task that must be done is a new thing for students. Therefore, problem-solving is one way to encourage creativity or creative thinking skills of students. Thus, problem-solving can be an approach to find out the students' creative thinking abilities.

\section{Extrovert and Introvert Personality Types}

Personality is an essential nature of the individual which is reflected in the attitudes and actions that distinguish themselves from others (Winarso, 2015). Personality type is a classification of individuals in one or two or more categories, based on the close pattern of their nature that matches the type of category earlier (Aliyah, 2006).

According to personality theorist, Carl Gustav Jung, there are two types of personality, namely extrovert and introvert. Both types of personality according to Jung's theory have their characteristics. Introvert personality has a characteristic when dealing with something much influenced by subjective factors originating from the inner world itself while extrovert personality has a more open character and can be more sociable (Azizah, 2016). In other words, an extrovert is better known by its open nature and introvert better known by its closed nature. In this case, psychological functions can apply to the extrovert and introvert in touch with the world around that sensation (sensing), intuition (intuiting), thinking (thinking), and feeling (feeling). 


\section{METHODS}

The research method used in this research is descriptive with a qualitative approach. Qualitative descriptive research is research where the data is not in the form of numbers, but a description of words. The qualitative method is used to get indepth data, data that contains meaning. Meaning is actual data, definite data which is a value behind the visible data. Therefore, qualitative research does not emphasize generalization but rather emphasizes meaning (Sugiyono, 2014).

Research designs in qualitative research, it is possible to have a variety of forms, flexible, or to be changed to adjust based on the plan that has been made, with the symptoms that exist at the actual research site. For this reason, this research was carried out in stages as Moleong (2013, p. 127) said, that there were several stages of research in general, consisting of the pre-field stage, the stage of fieldwork, and the stage of data analysis.

The research subjects were 4 students of class X IPS MA An-Nur Cirebon city even semester 2018/2019 academic year selected based on consideration of personality test results. The instruments used were interviews, personality tests, and creative thinking skills tests. Data analysis techniques include (1) data reduction, (2) triangulation, (3) data presentation, and (4) concluding.

\section{RESULT AND DISCUSSION}

\section{a. Description of the test result}

The results of this study consisted of grouping personality types obtained from personality tests, results of mathematical problem-solving tests, and the results of interviews with research subjects. The first data collection was done by giving personality test sheets to all students of class X IPS MA An-Nur Cirebon, which amounted to 31 students. Based on the test results obtained 16 students who tend extroverted personality types, 11 students who have introverted personality type tendencies, and 4 other students who have ambitious personality type tendencies (students who are not included in the two personality types).

After conducting a personality test and the results obtained as already mentioned, then determined the research subject for further analysis. Researchers have determined 4 students with different personality types as research subjects, namely 2 students with extrovert personality types and 2 students with introvert personality types. The taking of the subject is based on the consideration of students' abilities (average math scores) and also the advice of the mathematics teacher.

Table 1

List of Research Subjects

\begin{tabular}{ccc}
\hline Subject & Personality type \\
\cline { 1 - 1 } E. 1 & & Extrovert \\
E. 2 & & Extrovert \\
I. 1 & & Introverted \\
I.2 & Introverted \\
\hline
\end{tabular}

Specified research subjects were then asked to work on math problem-solving test questions that were conducted in writing. After working on the test questions, the subjects were asked to be interviewed. Interviews were conducted to strengthen the data obtained through test results in the data analysis process.

The written test results are then analyzed to determine the level of creative thinking ability of students based on three indicators of creative thinking ability, namely, fluency, flexibility, and novelty as the table below:

Table 2

Gaps in Creative Thinking Ability

\begin{tabular}{|c|c|}
\hline Level & Characteristics \\
\hline $\begin{array}{c}\text { Level } 4 \text { (Very } \\
\text { creative) }\end{array}$ & $\begin{array}{c}\text { Students can } \\
\text { demonstrate fluency, } \\
\text { flexibility, and novelty } \\
\text { in solving problems } \\
\text { and raising problems }\end{array}$ \\
\hline
\end{tabular}


Level 3

(Creative)

Level 2

(Quiet

creative)

Level 1 (Less

creative)

Level 0 (Not creative)
Students can demonstrate fluency and novelty or fluency and flexibility in solving problems and raising problems

Students can show novelty or flexibility in solving problems and raising problems

$$
\begin{gathered}
\text { Students can show } \\
\text { fluency in solving } \\
\text { problems and raising } \\
\text { problems }
\end{gathered}
$$

Students are unable to show all three aspects of indicators of creative thinking

Previously, the personality test instrument was validated by two lecturers of IAIN Sheikh Nurjati Cirebon after a revision so that it could be used immediately. Likewise with the creative thinking ability test instrument that has been validated by 2 validators, namely Tadris Mathematics lecturer IAIN Sheikh Nurjati Cirebon and mathematics teacher MA An-Nur Cirebon. Based on the two validator's suggestions, the researcher revised the creative thinking ability test instrument before finally it was validated so that it could be used immediately.

\section{Subject E.1}

When solving trigonometric material problems, the first thing an extrovert (E.1) type subject does is read the problem first and then understand the problem. At this stage, what is considered as an indicator of creative thinking is fluency, flexibility, and novelty.

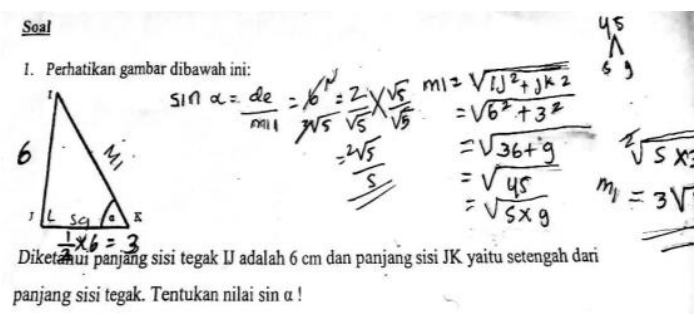

Figure 1 Subject written test results E.1
Based on written test results and interview results, it is known that the subject reads the questions repeatedly, this is because the subject does not understand if in one reading. After reading it over and over, the subject finally succeeded in explaining his understanding of the purpose of the problem and the information he obtained. The subject can explain again using his language. The subject also makes a plan to solve the problem asked in the problem by linking his prior knowledge so that he can find a solution to solve it.

\section{Subject E.2}

When completing a trigonometric material problem, this extrovert (E.2) type subject immediately works on the problem from the problem after reading the question once. To understand the purpose of the problem, the subject looks to ask the next friend. At this stage, what is considered as an indicator of creative thinking is fluency, flexibility, and noveltaly.

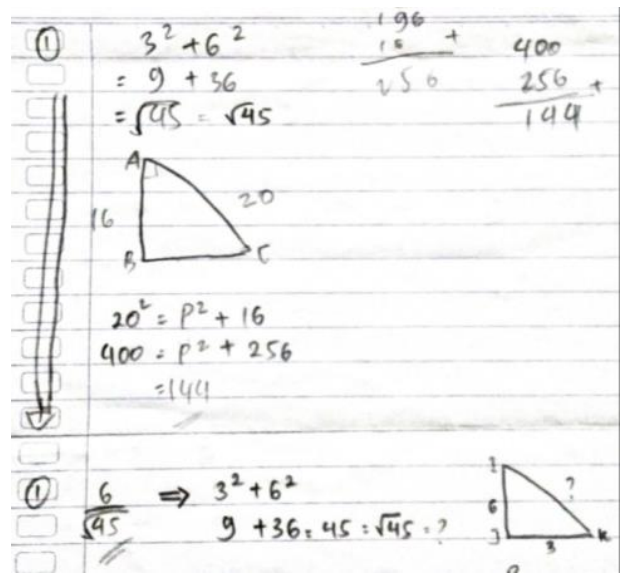

Figure 2 Subject written test results E.2

Based on written test results and interview results, it is known that the subject reads the question only once, but to better understand it the subject chooses to ask his friend. After that, the subject finally succeeded in explaining his understanding of the purpose of the problem and the information he obtained. The subject can explain again using his language. The subject also has made a plan to solve the problem that was asked 
in the problem using the Pythagorean theorem, but the subject did not continue the answer until what was asked in the problem. Therefore, the subject did not get the desired answer.

\section{Subject I.1}

When completing a trigonometric material problem, the first thing an introverted (I.1) type subject does is read the problem two to three times to try to understand the purpose of the problem. At these stages, what considered an indicator of creative thinking is fluency, flexibility, and novelty.

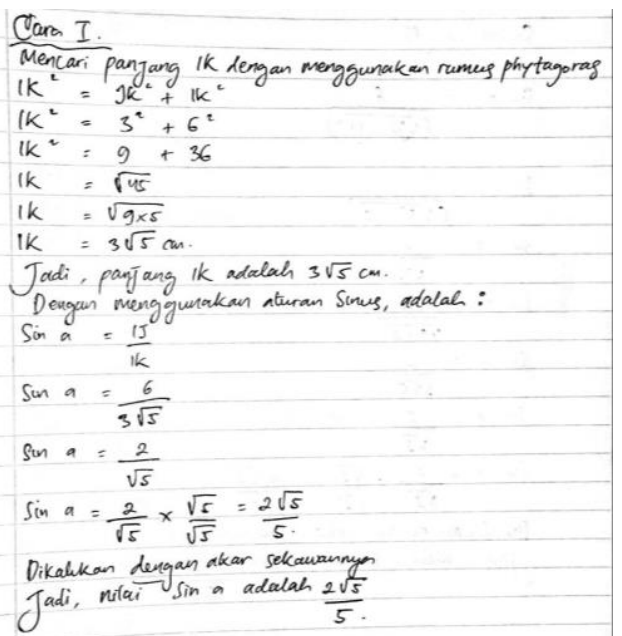

Figure 3 The results of the written test subject I. 1 the first way

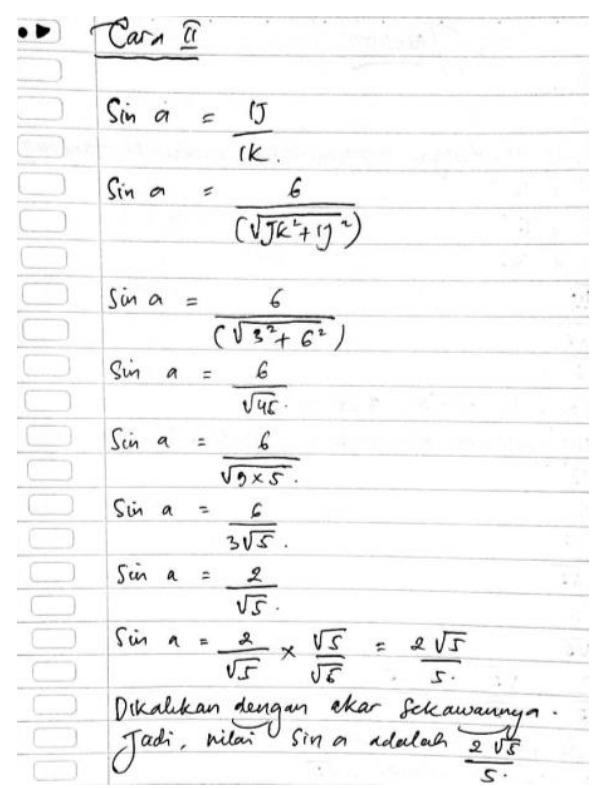

Figure 4 Written test results for subject I. 1 second method
Based on the written test results and interview results, it is known that the subject reads the questions in-depth to get the intention of the questions given. The subject can explain again using his language. Based on his previous knowledge, the subject has planned a solution that is used in solving the problem by using the Pythagorean theorem. Next, the subject gives two alternative ways of solving it with the same answer.

\section{Subject I.2}

When completing a trigonometric material problem, the first thing an introvert (I.2) type subject does is read the problem several times while understanding the meaning of the problem. At this stage, what is considered as an indicator of creative thinking is fluency, flexibility, and novelty.

$$
\begin{aligned}
& \text { Jawaibani } \\
& I K^{2}=J K^{2}+I J^{2} \\
& I K^{2}=3^{2}+6^{2} \\
& I K=9+36 \\
& I K=\sqrt{45} \\
& I K=\sqrt{9 \times 5} \\
& I K=3 \sqrt{5} \mathrm{~cm} \\
& \therefore \text { parijang IK adalah } 3 \sqrt{5} \mathrm{~cm} \\
& \text { menentukzan nilai sinues } \alpha \\
& \text { sin } \alpha=\frac{\text { de }}{\text { mi }}=\frac{I J}{I K}=\frac{6}{3 \sqrt{5}}=\frac{2}{\sqrt{5}}=\frac{2}{\sqrt{5}} \times \frac{\sqrt{5}}{\sqrt{5}}=\frac{2 \sqrt{5}}{5} \\
& \text { Izdi, nilai fin } \alpha \text { dalah } \frac{2 \sqrt{5}}{5} \\
&
\end{aligned}
$$

Figure 5 The results of the written test subject I.2 the first way

Based on written test results and interview results, it is known that the subject reads the questions in-depth to get the intent of the questions given. The subject can explain again the purpose of the problem smoothly with his language. Based on his previous knowledge, the subject has planned a solution that is used in solving the problem by using the Pythagorean theorem. Next, the subject 
gives two alternative ways of solving it with the same answer.

\section{b. Data Analyze}

Based on the results of tests and interviews of the four subjects, it is known that students' creative thinking abilities in solving mathematical problems in terms of extroverted personality types show students have difficulty understanding the problems that exist in the problem so they have to read it over and over again. Therefore, not all indicators of creative thinking ability are met by students who tend this extrovert personality type. One indicator that is met is fluency. As for other indicators not yet met. In the indicator of flexibility, students do not provide alternative answers using different ways. This is also evident from the results of the interview which stated that the subject found it difficult to find a different way whereas, for the novelty indicator, the subject only focused on solving the problem in one way so that it did not provide new ideas in solving this problem.

Conversely, students' creative thinking abilities in solving mathematical problems in terms of introverted personality types show students are quite understanding the problems that exist in the problem even though they must remain careful in reading it. Therefore, not all indicators of creative thinking ability are met by students who have this introverted personality type of tendency. Indicators of creative thinking ability that are met are fluency and flexibility.

The subject can explain the purpose of the problem found in the problem again. The subject also met the indicator of flexibility, namely by providing alternative answers on the written sheet using a different method or the other. This is evident from the results of interviews that state that the subjects have provided different ways according to what they know. However, the subject did not give a new idea in solving this problem so it did not meet the newness indicator.
If seen from each of the discussions that have been described above, the difference is clear. In this case, students' creative thinking abilities in mathematical problem-solving in terms of extroverted personality types meet the level of creative thinking ability 1 (less creative) while the creative thinking abilities of students in mathematical problemsolving in terms of personality type introvert meet the level of creative thinking ability 3 (creative). To see more clearly, below this table has presented a description of the differences between the two.

Table 3

Differences in Students' Creative Thinking Ability for Extrovert and Introvert Personality Types

\begin{tabular}{|c|c|c|c|c|}
\hline Indicator & E.1 & E.2 & I. 1 & I. 2 \\
\hline Fluency & $\sqrt{ }$ & $\sqrt{ }$ & $\sqrt{ }$ & $\sqrt{ }$ \\
\hline Flexibility & - & - & $\sqrt{ }$ & $\sqrt{ }$ \\
\hline Novelty & - & - & - & - \\
\hline
\end{tabular}

Based on the presentation of the table above, it can be seen that subjects who have introvert personality type tendencies already meet two indicators among the three indicators, namely fluency and flexibility.

Therefore, students 'creative thinking abilities in solving mathematical problems reviewed from introverted personality types can be said to meet the level of creative thinking aptitude which tends to be higher than students' creative thinking abilities in solving mathematical problem solving from extrovert personality types.

\section{CONCLUSION AND IMPLICATION}

\section{a. Conclusion}

Based on the results of research and discussion, it can be concluded that the analysis of students' ability to think creatively in solving mathematical 
problems in terms of extrovert and introvert personality type is as follows: 1. Students who have a tendency extrovert personality types are at the level of creative thinking abilities 1 (less creative), namely, students do not understand the problem and only meet the indicators of fluency creative thinking abilities while the other two indicators, namely flexibility and novelty have not been met 2 . Students who have introvert personality type tendencies are at the level of creative thinking abilities 3 (creative), namely students simply understands the problem and has fulfilled two indicators of creative thinking ability, namely eloquence, and flexibility while for the indicator of the ability to think creatively newness has not been met.

\section{b. Implication}

Since the results of the study indicate that indicators of flexibility and novelty have not been fulfilled in students with extrovert personality types, it is expected that further researchers can research the indicators that have not been met, both in quantitative, qualitative and mixed approaches.

\section{ACKNOWLEDGMENTS}

The writing of this article is inseparable from the assistance of the supervisor and other parties who have helped so that the author can complete this article. Therefore, the authors would like to thank the supervisor and all parties who have helped write this article.

\section{REFERENCES}

Aliyah, P. (2006). Hubungan Tipe Kepribadian Ekxtrovert dan Introvert dengan Perilaku Asertif pada Siswa-siswi Pesantren X di Bogor. Bogor: Universitas Bina Nusantara.

Anwar, N. T. (2018, February). Peran Kemampuan Literasi Matematis pada Pembelajaran Matematika Abad-21. In Prisma, Prosiding Seminar Nasional Matematika (Vol. 1, pp. 364-370). Retrieved from

https://journal.unnes.ac.id/sju/inde x.php/prisma/article/view/19603

Azizah, Y. N., Herdaetha, A., \& KJ, S. (2016). Perbedaan Antara Tipe Kepribadian Ekstrovert dan Introvert dengan Tingkat Stres pada Mahasiswa Fakultas Hukum Universitas Muhammadiyah Surakarta (Doctoral dissertation, Universitas Muhammadiyah Surakarta). Retrieved from http://eprints.ums.ac.id/42833/

Hasanah, N., Mardiyana, M., \& Sutrima, S. (2013). Analisis Proses Berpikir Siswa dalam Memecahkan Masalah Matematika Ditinjau dari Tipe Kepribadian Extrovertintrovert dan Gender. Jurnal Pembelajaran Matematika, 1(4).422-434. Retrieved from https://jurnal.uns.ac.id/jpm/article/ view/10292

Kuswana, W. S. (2011). Taksonomi Berpikir. Bandung: PT Remaja Rosdakarya.

Lestari \& Yudhanegara. (2017). Penelitian Pendidikan

Matematika. Bandung: PT Refika Aditama.

Moleong, L. J. (2013). Metodologi Penelitian Kualitatif. Bandung: PT. Remaja Rosdakarya.

Purwosusilo. (2014). Peningkatan Kemampuan Pemahaman dan Pemecahan Masalah Matematika Siswa SMK Melalui Strategi Pembelajaran REACT (Studi Eksperimen di SMK Negeri 52 Jakarta). Jurnal Pendidikan Dan Keguruan, 1(2), 30-40. 
Siswono, T. Y. (2007). Penjenjangan Kemampuan Berpikir Kreatif dan Identifikasi Tahap Berpikir Kreatif dalam Memecahkan dan Mengajukan Masalah Matematika. Disertasi: Unesa Surabaya.

Siswono, T. Y. E. (2018). Pembelajaran Matematika Berbasis Pengajuan Masalah: Fokus pada Berpikir Kritis dan Berpikir Kreatif. Bandung: Rosda Karya.

Sugiyono. (2014). Memahami Penelitian Kualitatif. Bandung: Alfabeta.

Sunandar, Y., \& Muchyidin, A. (2016). Perbandingan Kemampuan Berpikir Kreatif Matematika Siswa Antara yang Menggunakan Penilaian Tugas dengan Penilaian Portofolio dalam Pembelajaran Matematika. Eduma: Mathematics Education Learning and Teaching, 5(1). 47-55. Retrieved from http://www.syekhnurjati.ac.id/jurn al/index.php/eduma/article/view/6 $\underline{82}$

Tho'atillah. (2018). Perbedaan Kemampuan Pemecahan Masalah Matematika Siswa Antara yang Menggunakan Metode Peer Teaching dengan Metode Resitasi di SMP Negeri 2 Krangkeng.
(Doctoral dissertation, IAIN Syekh Nurjati Cirebon)

Widodo, W. (2015). Perbedaan tipe kepribadian terhadap sikap belajar matematika siswa kelas X SMA Islam Al-Azhar 5 Cirebon. Sainsmat: Jurnal Ilmiah Ilmu Pengetahuan Alam, 4(1).67-80. https://doi.org/10.18592/jpm.v2i1.1170

Yusuf, S., \& Nurihsan, A. J. (2012). Teori Kepribadian. Bandung: PT Remaja Rosdakarya. 